\title{
The current state of H5N1 vaccines and the use of the ferret model for influenza therapeutic and prophylactic development
}

\author{
David Banner ${ }^{1}$ and Alyson A. Kelvin ${ }^{2}$ \\ ${ }^{1}$ Division of Experimental Therapeutics, Toronto General Research Institute, University Health Network, Toronto, \\ Ontario, Canada \\ ${ }^{2}$ Immune Diagnostics \& Research, Toronto, Ontario, Canada
}

\begin{abstract}
Highly pathogenic avian influenza $\mathrm{H} 5 \mathrm{~N} 1$ is a threat to global public health as a natural pandemic causing agent but has recently been considered a bioterrorism concern. The evolving view of the $\mathrm{H} 5 \mathrm{~N} 1$ virus necessitates the re-evaluation of the current status of $\mathrm{H} 5 \mathrm{~N} 1$ therapeutics and prophylactics, in particular the preparation of viable $\mathrm{H} 5 \mathrm{~N} 1$ vaccination strategies as well as the use of ferrets in influenza research. Here the highly pathogenic H5N1 virus dilemma is discussed in context with the current $\mathrm{H} 5 \mathrm{~N} 1$ vaccine status and the use of the ferret model. Previously, the development of various H5N1 vaccine platforms have been attempted, many of them tested in the ferret model, including vector vaccines, adjuvant vaccines, DNA vaccines, and reverse engineered vaccines. Moreover, as ferrets are a superlative animal model for influenza investigation and vaccine testing, it is imperative that this model is recognized for its uses in prophylactic development and not only as an agent for creating transmissible influenza viruses. Elucidating the ferret immune response and creating ferret immune reagents remain important goals in conjunction with the development and manufacture of H5N1 vaccines. In summary, an efficacious H5N1 vaccine is urgently needed and the ferret model remains an appropriate model for its development.
\end{abstract}

J Infect Dev Ctries 2012; 6(6):465-469.

(Received 27 March 2012 - Accepted 30 April 2012)

Copyright (C) 2012 Banner and Kelvin. This is an open-access article distributed under the Creative Commons Attribution License, which permits unrestricted use, distribution, and reproduction in any medium, provided the original work is properly cited

Highly pathogenic avian influenza H5N1 (HPAI $\mathrm{H} 5 \mathrm{~N} 1$ ) is a threat to global public health as a natural pandemic causing agent but recently there has been a great deal of controversy surrounding the possibility of $\mathrm{H} 5 \mathrm{~N} 1$ as a biosecurity or bioterrorism risk $[1,2]$. As a natural pandemic threat, an approximately $60 \%$ mortality rate has been calculated for HPAI H5N1 virus in infected humans [3]. Furthermore, if this virus acquired human-to-human transmission capability, it is predicted that an unprecedented lethal pandemic would possibly ensue in the global naïve human population. Recently, the laboratory development of an aerosol transmissible H5N1 virus has been published [4] and a similar study is in waiting. These studies have ignited a serious debate on whether an aerosol transmissible $\mathrm{H} 5 \mathrm{~N} 1$ virus can be utilized for bioterrorist objectives or are a biosecurity danger [1,5-7]. It is important to recognize that the scientific aim and rationale of these investigations was to determine the capability of HPAI H5N1 to acquire aerosol transmission and to elucidate possible mechanisms of aerosol transmission in the ferret model, a natural influenza host. The researchers contend that these findings will contribute significantly to $\mathrm{H} 5 \mathrm{~N} 1$ virus therapeutic and prophylactic development[5] .

The results of these $\mathrm{H} 5 \mathrm{~N} 1$ ferret transmission studies represent the second facet of concern for H5N1 as a biosecurity and bioterrorism hazard which has been heavily debated [1,5-7]. The publicity that was generated from this work prompted a 60-day international hold on $\mathrm{H} 5 \mathrm{~N} 1$ influenza transmission research. Furthermore, this controversy sparked a call for redaction of the full results by the United States National Science Advisory Board for Bioscecurity (NSABB) in these soon-to-be published papers[5,6]. The NSABB labeled the technologies established in these seminal studies as "dual use research of concern," i.e., research having the potential to be used for good or bad purposes [1,5,7]. With this possibility in mind, HPAI H5N1 not only remains a highly virulent natural pandemic threat, but the deliberate misuse of a human developed aerosol transmissible $\mathrm{H} 5 \mathrm{~N} 1$ virus is a concern. With controversy surrounding the $\mathrm{H} 5 \mathrm{~N} 1$ virus and its natural pandemic causing potential, it is now more important than ever to discuss and evaluate the timely 
development of $\mathrm{H} 5 \mathrm{~N} 1$ therapeutics and prophylactics, including the preparation and efficacy of viable $\mathrm{H} 5 \mathrm{~N} 1$ vaccination strategies.

Estimates place the financial burden of a highly virulent pandemic to be in the neighborhood of 200 billion US dollars in the United States alone [2]. The ideal strategy in combating an eminent pandemic is producing pre-breakout prepared influenza vaccines, which further implies the need for immediate vaccine strategy development. Previously, researchers have attempted to create HPAI H5N1 vaccine candidates with non-pathogenic yet antigenically related nonpathogenic viruses; however, these attempts have had little success [8].

Currently, various $\mathrm{H} 5 \mathrm{~N} 1$ vaccines are being developed including vector vaccines, adjuvant vaccines, DNA vaccines, and reverse engineered vaccines, although there are several points to consider for their development. Controversy exists around the method of vaccine type and vaccine production. The US stockpile of H5N1 vaccine to A/Viet Nam/1194/2004 is propagated in embryonated chicken eggs despite the problems that are associated with the use of chicken eggs in the event of a pandemic avian virus $[9,10]$. Dangers in the use of chicken eggs as well as the availability of chicken eggs are major concerns in an avian derived influenza pandemic [11]. Furthermore, the World Health Organization promotes cell-based $\mathrm{H} 5 \mathrm{~N} 1$ influenza vaccine technologies using either Vero or MDCK cells and efforts are being made to investigate the production of cell-based H5N1 vaccines $[10,12,13]$. Other issues to consider with the development of an HPAI H5N1 vaccine include the propensity of genetic drift and shift of the influenza virus. As genetic drift and shift of influenza viruses may result in antigenically distinct viruses, a shifted or drifted HPAI H5N1 may render a previously manufactured vaccine ineffective.

Presently in the US, two types of broad influenza strain egg/cell-derived vaccine platforms are approved for clinical use: live attenuated influenza vaccines (LAIVs) and inactivated influenza vaccines (whole/subvirion) [2,14]. Examples of inactivated influenza vaccines include the current 2011-2012 seasonal trivalent influenza vaccine FluLaval produced by GlaxoSmithKline (Brentford, UK) [15]. FluLaval is a composition of three heat-inactivated influenza viruses recommended by the WHO:
A/California/7/2009 (H1N1)-like virus, an $\mathrm{A} /$ Perth/16/2009 (H3N2)-like virus, and a $\mathrm{B} /$ Brisbane/60/2008-like virus (B Victoria lineage) $[15,16]$.

LAIVs have various advantages over the inactive virus vaccines including a greater immune response and efficacy [2]. LAIVs are often developed by coldadaptation, influenza virus reassortants and/or genetically modified influenza virus technology. Importantly, the reverse engineered virus platform is a conglomerate of a basic non-pathogenic backbone of an innocuous influenza virus and the immunogenic proteins of the pathogenic influenza strain of interest. Currently, the non-pathogenic backbone of the coldadapted, live attenuated viruses is the FDA-approved LAIV against seasonal influenza strain (A/AnnArbor/6/1960CaH2N2), which easily grows to high titres for mass production at cold temperatures [2]. Furthermore, the $\mathrm{H} 5 \mathrm{~N} 1 \mathrm{rg}$ vaccine contains the immunogenic proteins from pathogenic $\mathrm{H} 5 \mathrm{~N} 1$ viruses and the nonpathogenic backbone proteins from the A/PR/8/1934 virus [10]. Although concerns exist over the use of cold-adapted LAIVs, several studies have shown these vaccines have been are effective and safe [17-19].

As non-pathogenic antigentically related native H5N1 virus vaccines have had little success, efforts have been made in the development of an $\mathrm{H} 5 \mathrm{~N} 1$ LAIV using reverse genetic techniques with cold adapted viruses [16]. Previously, a polybasic amino acid region at the HA cleavage site has been identified as a key region responsible for $\mathrm{H} 5 \mathrm{~N} 1$ pathogenicity [20,21]. Importantly, this identified polybasic aa section adjacent to the cleavage site can be manipulated to create a virus of less pathogenicity for the use in LAIV derivation [10,21,22]. Investigations of reverse engineered $\mathrm{H} 5 \mathrm{~N} 1$ vaccines for $\quad \mathrm{rg}-\mathrm{A} / \mathrm{Vietnam} / 1203 / 2004, \quad \mathrm{rg}$ $\mathrm{A} /$ Indonesia/05/2005 and $\mathrm{rg}-\mathrm{A} /$ Anhui/1/2005 have been completed [23-25]. Although these vaccines did not show the hoped efficacy [16;21], this vaccination platform represents an important route for further investigation.

With the current controversy surrounding the use of ferrets in influenza studies, it is important to remember that the reason for using ferrets extends far beyond that of providing a model for H5N1 transmission, as many investigators have shown ferrets to be a superlative platform for testing and 
developing influenza therapeutics including the investigation of influenza vaccines [26-30]. Importantly, when infected with respiratory viruses, ferrets display many of the symptoms and pathological features seen in infected humans [3133] . Ferret immune responses have been shown to mimic the immune response of humans, which makes the ferret an appropriate tool for the investigation of human diseases, including H5N1. Furthermore, each influenza strain and subtype is characterized by a unique set of clinical features and innate and adaptive immunological signatures following infection with pandemic $\mathrm{H} 1 \mathrm{~N} 1$, seasonal $\mathrm{H} 1 \mathrm{~N} 1$, seasonal $\mathrm{H} 3 \mathrm{~N} 2$, and influenza $B$ viruses [34]. As well, the characterization of ferret cytokines and immune molecules, essential components to the evaluation of therapeutics and the immune response during pathogenic virus have been previously described [3537]. Currently, ferrets are used for influenza drug testing; for example, neuraminidase inhibitors are effective during ferret influenza infection [38-40]. Importantly, ferrets display immunological memory and cross-protective immunity, the cornerstones of vaccine mechanism, and are therefore ideal for the use of testing the safety and efficacy of human vaccines [41-45].

The diverse and broad antigenicity of H5N1 isolates renders it very difficult to accurately predict which types of vaccines would be effective against a potential H5N1 pandemic. The ferret is also an ideal model for testing a variety of experimental vaccines and their effectiveness in reducing illness caused by infections by candidate H5N1 strains. Moreover, due to its natural susceptibility to human influenza, the ferret is used extensively to generate hyperimmune sera against seasonal influenza viruses. As well, the use of reverse genetics has enabled the production of antisera against highly pathogenic influenza viruses without causing severe illness to the animals [46]. If an outbreak of $\mathrm{H} 5 \mathrm{~N} 1$ were to occur in humans either by natural exposure or through a laboratory release, ferret H5N1 virus- and vaccine-specific antisera will be critical for both the identification of infectious virus strains and the rapid prediction of which vaccines will be effective.

\section{References}

1. Palese P, Wang TT (2012) H5N1 influenza viruses: Facts, not fear. Proc Natl Acad Sci U S A . 1121297109 [pii];10.1073/pnas.1121297109 [doi].

2. Singh N, Pandey A, Mittal SK (2010) Avian influenza pandemic preparedness: developing prepandemic and pandemic vaccines against a moving target 1 . Expert Rev Mol Med 12: e14. S1462399410001432 [pii];10.1017/S1462399410001432 [doi].

3. World Health Organization (WHO) (2012) Cumulative number of confirmed human cases for avian influenza $\mathrm{A}(\mathrm{H} 5 \mathrm{~N} 1)$ reported to WHO, 2003-2012.

4. Imai M, Watanabe T, Hatta M, Das SC, Ozawa M, Shinya K, Zhong G, Hanson A, Katura H, Watanabe S, Li C, Kawakami E, Yamada S, Kiso M, Suzuki Y, Maher EA, Neumann G, Kawaoka Y (2012) Experimental adaptation of an influenza H5 HA confers respiratory droplet transmission to a reassortant $\mathrm{H} 5 \mathrm{HA} / \mathrm{H} 1 \mathrm{~N} 1$ virus in ferrets. Nature .

5. Berns KI, Casadevall A, Cohen ML, Ehrlich SA, Enquist LW, Fitch JP, Franz DR, Fraser-Liggett CM, Grant CM, Imperiale MJ, Kanabrocki J, Keim PS, Lemon SM, Levy SB, Lumpkin JR, Miller JF, Murch R, Nance ME, Osterholm MT, Relman DA, Roth JA, Vidaver AK (2012) Adaptations of Avian Flu Virus Are a Cause for Concern. Science . science.1217994 [pii];10.1126/science.1217994 [doi].

6. Fouchier RA, Garcia-Sastre A, Kawaoka Y, Barclay WS, Bouvier NM, Brown IH, Capua I, Chen H, Compans RW, Couch RB, Cox NJ, Doherty PC, Donis RO, Feldmann H, Guan Y, Katz J, Klenk HD, Kobinger G, Liu J, Liu X, Lowen A, Mettenleiter TC, Osterhaus AD, Palese P, Peiris JS, Perez DR, Richt JA, Schultz-Cherry S, Steel J, Subbarao K, Swayne DE, Takimoto T, Tashiro M, Taubenberger JK, Thomas PG, Tripp RA, Tumpey TM, Webby RJ, Webster RG (2012) Pause on avian flu transmission research2. Science 335: 400-401. 335/6067/400 [pii];10.1126/science.335.6067.400 [doi].

7. Webster RG (2012) Mammalian-Transmissible H5N1 Influenza: the Dilemma of Dual-Use Research 2. MBio 3. mBio.00005-12 [pii];10.1128/mBio.00005-12 [doi].

8. Takada A, Kuboki N, Okazaki K, Ninomiya A, Tanaka H, Ozaki H, Itamura S, Nishimura H, Enami M, Tashiro M, Shortridge KF, Kida H (1999) Avirulent Avian influenza virus as a vaccine strain against a potential human pandemic. J Virol 73: 8303-8307.

9. Alexander J, Ward S, Mendy J, Manayani DJ, Farness P, Avanzini JB, Guenther B, Garduno F, Jow L, Snarsky V, Ishioka G, Dong X, Vang L, Newman MJ, Mayall T (2012) Pre-clinical evaluation of a replication-competent recombinant adenovirus serotype 4 vaccine expressing influenza h5 hemagglutinin 1. PLoS One 7: e31177. 10.1371/journal.pone.0031177 [doi];PONE-D-11-18736 [pii].

10. Nicolson C, Major D, Wood JM, Robertson JS (2005) Generation of influenza vaccine viruses on Vero cells by reverse genetics: an $\mathrm{H} 5 \mathrm{~N} 1$ candidate vaccine strain produced under a quality system3. Vaccine 23: 2943-2952. S0264-410X(04)00915-6 [pii];10.1016/j.vaccine.2004.08.054 [doi].

11. Wood JM, Robertson JS (2004) From lethal virus to lifesaving vaccine: developing inactivated vaccines for pandemic influenza 15. Nat Rev Microbiol 2: 842-847. 10.1038/nrmicro979 [doi];nrmicro979 [pii]. 
12. [Anonymous] (2006) WHO 2006 Global pandemic influenza action plan to increase vaccine supply. WHO .

13. Tseng YF, Hu AY, Huang ML, Yeh WZ, Weng TC, Chen YS, Chong P, Lee MS (2011) Adaptation of high-growth influenza $\mathrm{H} 5 \mathrm{~N} 1$ vaccine virus in Vero cells: implications for pandemic preparedness 1. PLoS One 6: e24057. 10.1371/journal.pone.0024057 [doi];PONE-D-11-03637 [pii].

14. Ilyinskii PO, Thoidis G, Shneider AM (2008) Development of a vaccine against pandemic influenza viruses: current status and perspectives 3. Int Rev Immunol 27: 392-426. 906496079 [pii]; $10.1080 / 08830180802295765$ [doi].

15. GSK (2012) FluLaval GSK: Product Information Sheet.

16. CCDR and PHAC (2012) Statement on Seeasonal Influenza Vaccine for 2011-2012. CCDR Canada Communicable Disease Report .

17. Belshe RB, Toback SL, Yi T, Ambrose CS (2010) Efficacy of live attenuated influenza vaccine in children 6 months to 17 years of age 11. Influenza Other Respi Viruses 4: 141145. IRV124 [pii];10.1111/j.1750-2659.2009.00124.x [doi].

18. Belshe RB, Edwards KM, Vesikari T, Black SV, Walker RE, Hultquist M, Kemble G, Connor EM (2007) Live attenuated versus inactivated influenza vaccine in infants and young children 24. N Engl J Med 356: 685-696. 356/7/685 [pii];10.1056/NEJMoa065368 [doi].

19. Ashkenazi S, Vertruyen A, Aristegui J, Esposito S, McKeith DD, Klemola T, Biolek J, Kuhr J, Bujnowski T, Desgrandchamps D, Cheng SM, Skinner J, Gruber WC, Forrest BD (2006) Superior relative efficacy of live attenuated influenza vaccine compared with inactivated influenza vaccine in young children with recurrent respiratory tract infections 8 . Pediatr Infect Dis J 25: 870879. 10.1097/01.inf.0000237829.66310.85 [doi];00006454200610000-00004 [pii].

20. Hatta M, Gao P, Halfmann P, Kawaoka Y (2001) Molecular basis for high virulence of Hong Kong H5N1 influenza A viruses $20 . \quad$ Science 293: $1840-1842$. 10.1126/science.1062882 [doi];293/5536/1840 [pii].

21. Govorkova EA, Rehg JE, Krauss S, Yen HL, Guan Y, Peiris M, Nguyen TD, Hanh TH, Puthavathana P, Long HT, Buranathai C, Lim W, Webster RG, Hoffmann E (2005) Lethality to ferrets of $\mathrm{H} 5 \mathrm{~N} 1$ influenza viruses isolated from humans and poultry in 2004 34. J Virol 79: 2191-2198. 79/4/2191 [pii];10.1128/JVI.79.4.2191-2198.2005 [doi].

22. Gabriel G, Garn H, Wegmann M, Renz H, Herwig A, Klenk HD, Stech J (2008) The potential of a protease activation mutant of a highly pathogenic avian influenza virus for a pandemic live vaccine 3. Vaccine 26: 956-965. S0264410X(07)01369-2 [pii];10.1016/j.vaccine.2007.11.052 [doi].

23. Bright RA, Ross TM, Subbarao K, Robinson HL, Katz JM (2003) Impact of glycosylation on the immunogenicity of a DNA-based influenza H5 HA vaccine. Virology 308: 270278. S0042682203000084 [pii].

24. Haynes JR, Dokken L, Wiley JA, Cawthon AG, Bigger J, Harmsen AG, Richardson C (2009) Influenza-pseudotyped Gag virus-like particle vaccines provide broad protection against highly pathogenic avian influenza challenge 3 . Vaccine 27: 530-541. S0264-410X(08)01521-1 [pii];10.1016/j.vaccine.2008.11.011 [doi].

25. Epstein SL, Kong WP, Misplon JA, Lo CY, Tumpey TM, Xu L, Nabel GJ (2005) Protection against multiple influenza A subtypes by vaccination with highly conserved nucleoprotein. Vaccine 23: 5404-5410. S0264410X(05)00546-3 [pii];10.1016/j.vaccine.2005.04.047 [doi].
26. Rowe T, Leon AJ, Crevar CJ, Carter DM, Xu L, Ran L, Fang Y, Cameron CM, Cameron MJ, Banner D, Ng DC, Ran R, Weirback HK, Wiley CA, Kelvin DJ, Ross TM (2010) Modeling host responses in ferrets during A/California/07/2009 influenza infection 5. Virology 401: 257-265. S0042-6822(10)00129-7 [pii];10.1016/j.virol.2010.02.020 [doi].

27. Danesh A, Cameron CM, Leon AJ, Ran L, Xu L, Fang Y, Kelvin AA, Rowe T, Chen H, Guan Y, Jonsson CB, Cameron MJ, Kelvin DJ (2011) Early gene expression events in ferrets in response to SARS coronavirus infection versus direct interferon-alpha2b stimulation1. Virology 409: 102-112. S0042-6822(10)00638-0 [pii];10.1016/j.virol.2010.10.002 [doi].

28. Kelvin AA, Banner D, Danesh A, Seneviratne C, Ochi A et al. (2012) Ferret TNF-a and IFN-g Immunoassays. Intech: Immunoassays. In press.

29. Cameron CM, Cameron MJ, Bermejo-Martin JF, Ran L, Xu L, Turner PV, Ran R, Danesh A, Fang Y, Chan PK, Mytle N, Sullivan TJ, Collins TL, Johnson MG, Medina JC, Rowe T, Kelvin DJ (2008) Gene expression analysis of host innate immune responses during Lethal H5N1 infection in ferrets 3. J Virol 82: 11308-11317. JVI.00691-08 [pii];10.1128/JVI.00691-08 [doi].

30. Suguitan AL, Jr., Cheng X, Wang W, Wang S, Jin H, Lu S (2011) Influenza H5 hemagglutinin DNA primes the antibody response elicited by the live attenuated influenza A/Vietnam/1203/2004 vaccine in ferrets 4. PLoS One 6: e21942. 10.1371/journal.pone.0021942 [doi];PONE-D-1107053 [pii].

31. Darnell ME, Plant EP, Watanabe H, Byrum R, St CM, Ward JM, Taylor DR (2007) Severe acute respiratory syndrome coronavirus infection in vaccinated ferrets 1 . J Infect Dis 196: 1329-1338. JID38489 [pii];10.1086/522431 [doi].

32. Martina BE, Haagmans BL, Kuiken $T$, Fouchier RA, Rimmelzwaan GF, van AG, Peiris JS, Lim W, Osterhaus AD (2003) Virology: SARS virus infection of cats and ferrets 6. Nature 425: 915. 10.1038/425915a [doi];425915a [pii].

33. Peltola VT, Boyd KL, McAuley JL, Rehg JE, McCullers JA (2006) Bacterial sinusitis and otitis media following influenza virus infection in ferrets 1. Infect Immun 74: 2562-2567. 74/5/2562 [pii];10.1128/IAI.74.5.25622567.2006 [doi].

34. Huang SS, Banner D, Fang Y, Ng DC, Kanagasabai T, Kelvin DJ, Kelvin AA (2011) Comparative analyses of pandemic H1N1 and seasonal H1N1, H3N2, and influenza B infections depict distinct clinical pictures in ferrets 3. PLoS One 6: e27512. 10.1371/journal.pone.0027512 [doi];PONED-11-09202 [pii].

35. Danesh A, Seneviratne C, Cameron CM, Banner D, Devries ME, Kelvin AA, Xu L, Ran L, Bosinger SE, Rowe T, Czub M, Jonsson CB, Cameron MJ, Kelvin DJ (2008) Cloning, expression and characterization of ferret CXCL10 5. Mol Immunol 45: 1288-1297. S0161-5890(07)00747-X [pii];10.1016/j.molimm.2007.09.018 [doi].

36. Ochi A, Danesh A, Seneviratne C, Banner D, Devries ME, Rowe T, Xu L, Ran L, Czub M, Bosinger SE, Cameron MJ, Cameron CM, Kelvin DJ (2008) Cloning, expression and immunoassay detection of ferret IFN-gamma. Dev Comp Immunol 32: 890-897. S0145-305X(08)00003-7 [pii];10.1016/j.dci.2007.12.008 [doi].

37. Danesh A, Banner D, Fang Y, Huang SSH, Kelvin DJ et al. (2012) Cloning and characterization of ferret CD8a and 
development of a ferret CD8a hybrid clone. Veterinary Immunology and Immunopathology. In press.

38. Mendel DB, Tai CY, Escarpe PA, Li W, Sidwell RW, Huffman JH, Sweet C, Jakeman KJ, Merson J, Lacy SA, Lew W, Williams MA, Zhang L, Chen MS, Bischofberger N, Kim CU (1998) Oral administration of a prodrug of the influenza virus neuraminidase inhibitor GS 4071 protects mice and ferrets against influenza infection 13. Antimicrob Agents Chemother 42: 640-646.

39. Govorkova EA, Ilyushina NA, Boltz DA, Douglas A, Yilmaz N, Webster RG (2007) Efficacy of oseltamivir therapy in ferrets inoculated with different clades of H5N1 influenza virus. Antimicrob Agents Chemother 51: 14141424. AAC.01312-06 [pii];10.1128/AAC.01312-06 [doi].

40. Yun NE, Linde NS, Zacks MA, Barr IG, Hurt AC, Smith JN, Dziuba N, Holbrook MR, Zhang L, Kilpatrick JM, Arnold CS, Paessler S (2008) Injectable peramivir mitigates disease and promotes survival in ferrets and mice infected with the highly virulent influenza virus, A/Vietnam/1203/04 (H5N1) 1. Virology 374: 198-209. S0042-6822(07)00856-2 [pii];10.1016/j.virol.2007.12.029 [doi].

41. Bouvier NM, Lowen AC (2010) Animal Models for Influenza Virus Pathogenesis and Transmission 6. Viruses 2: 1530-1563. 10.3390/v20801530 [doi].

42. Maher JA, DeStefano J (2004) The ferret: an animal model to study influenza virus 1. Lab Anim (NY) 33: 50-53. 10.1038/laban1004-50 [doi];laban1004-50 [pii].

43. Price GE, Soboleski MR, Lo CY, Misplon JA, Pappas C, Houser KV, Tumpey TM, Epstein SL (2009) Vaccination focusing immunity on conserved antigens protects mice and ferrets against virulent $\mathrm{H} 1 \mathrm{~N} 1$ and $\mathrm{H} 5 \mathrm{~N} 1$ influenza $\mathrm{A}$ viruses6. Vaccine 27: 6512-6521. S0264-410X(09)01240-7 [pii];10.1016/j.vaccine.2009.08.053 [doi].
44. Fang Y, Banner D, Kelvin AA, Huang SS, Paige CJ, Corfe SA, Kane KP, Bleackley RC, Rowe T, Leon AJ, Kelvin DJ (2012) Seasonal H1N1 influenza virus infection induces cross-protective pandemic H1N1 virus immunity through a CD8-independent, B cell-dependent mechanism2. J Virol 86: 2229-2238. JVI.05540-11 [pii];10.1128/JVI.05540-11 [doi].

45. Cherukuri A, Servat E, Woo J (2012) Vaccine-specific antibody secreting cells are a robust early marker of LAIVinduced B-cell response in ferrets 1. Vaccine 30: 237-246. S0264-410X(11)01754-3 [pii];10.1016/j.vaccine.2011.11.001 [doi].

46. Chen H, Matsuoka Y, Swayne D, Chen Q, Cox NJ, Murphy BR, Subbarao K (2003) Generation and characterization of a cold-adapted influenza A H9N2 reassortant as a live pandemic influenza virus vaccine candidate5. Vaccine 21: 4430-4436. S0264410X03004304 [pii].

\section{Corresponding author}

Alyson A. Kelvin

Immune Diagnostics \& Research

Max Bell Research Centre

200 Elizabeth Street

Room 4R402

Toronto, Ontario, Canada

M5G 2C4

Telephone: 416-581-7608

Email: alyson@immunediagnosticsresearch.com

Conflict of interests: No conflict of interests is declared. 